
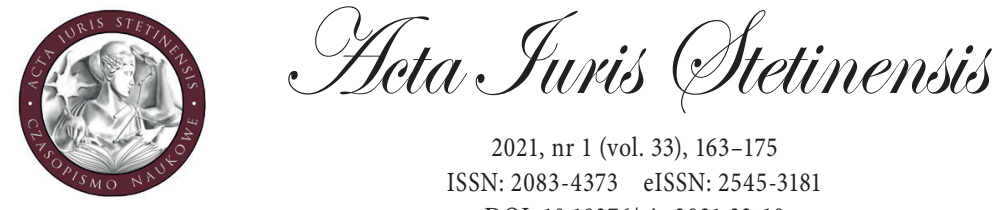

2021, nr 1 (vol. 33), 163-175

ISSN: 2083-4373 eISSN: 2545-3181

DOI: $10.18276 /$ ais.2021.33-10
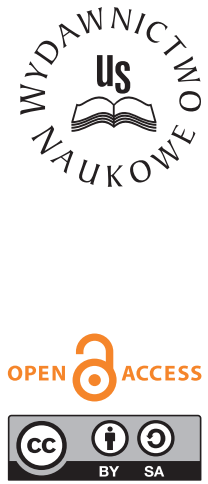

\title{
Wyrok Sądu Apelacyjnego w Szczecinie I Wydział Cywilny z dnia 16 lipca 2020 r., I ACa 509/19
}

Treść art. $359 \$ 21$ k.c. nie pozostawia jakichkolwiek wątpliwości co do tego, że odsetki wynikające z czynności prawnej nie mogą przekroczyć zdefiniowanych w tym przepisie odsetek maksymalnych. Odsetki jako świadczenie aktualizują się (stają się wymagalne) w każdym kolejnym dniu, toteż ocena ich dopuszczalności polegać musi na weryfikacji, czy w datach ich wymagalności (w praktyce każdego kolejnego dnia), wartość odsetek umownych naruszała bezwzględnie obowiązująca normę powołanego przepisu.

Sąd Apelacyjny w Szczecinie I Wydział Cywilny w składzie:

Przewodniczący: SSA Artur Kowalewski (spr.)

Sędziowie: SSA Ryszard Iwankiewicz

Protokolant: SSA Leon Miroszewski

po rozpoznaniu w dniu 16 lipca 2020 r., w Szczecinie, na posiedzeniu niejawnym sprawy z powództwa K.G. przeciwko P.G.I. spółce z ograniczoną odpowiedzialnością z siedzibą w G. o pozbawienie tytułów wykonawczych wykonalności na skutek apelacji powódki od wyroku Sądu Okręgowego w Gorzowie Wielkopolskim z dnia 21 marca 2019 r. sygn. akt I C 749/18:

I. Zmienia zaskarżony wyrok w ten sposób, że:

1. Pozbawia wykonalności tytuł wykonawczy w postaci nakazu zapłaty w postępowaniu upominawczym Sądu Rejonowego w Gorzowie Wielkopolskim z dnia 
7 czerwca 2006 r., sygn. akt X Nc 4355/06, zaopatrzonego w klauzulę wykonalności w dniu 17 listopada 2006 r. w części, a mianowicie:

a) co do odsetek umownych w wysokości 1\% dziennie za okres od dnia 8 czerwca 2006 r. do dnia 17 października 2011 r.,

b) co do odsetek umownych naliczonych od kwoty $600 \mathrm{zl}$, w wysokości 1\% dziennie w okresie od dnia 24 sierpnia 2004 r. do dnia 7 czerwca 2006 r. w zakresie kwoty $2.628,85 \mathrm{zt}$,

c) co do odsetek umownych w wysokości 1\% dziennie za okres od dnia 18 października 2011r. do dnia zapłaty $\mathrm{w}$ zakresie przewyższającym odsetki maksymalne, o których mowa w art. $359 \$ 21$ k.c., wynoszące do dnia 31 grudnia 2015 r. czterokrotność wysokości stopy kredytu lombardowego Narodowego Banku Polskiego, zaś od dnia 1 stycznia 2016 r., dwukrotność odsetek ustawowych stanowiących sumę stopy referencyjnej Narodowego Banku Polskiego i 3,5 punktów procentowych,

d) co do kosztów procesu w całości.

2. Pozbawia wykonalności tytuł wykonawczy w postaci nakazu zapłaty w postępowaniu upominawczym Sądu Rejonowego w Gorzowie Wielkopolskim z dnia 25 maja 2006 r., sygn. akt X Nc 4247/06, zaopatrzonego w klauzulę wykonalności w dniu 22 sierpnia 2006 r. w części, a mianowicie:

a) co do odsetek umownych w wysokości $1 \%$ dziennie za okres od dnia 26 maja 2006 r. do dnia 17 października 2011 r.,

b) co do odsetek umownych w wysokości $1 \%$ dziennie za okres od dnia 18 października 2011r. do dnia zapłaty $\mathrm{w}$ zakresie przewyższającym odsetki maksymalne, o których mowa w art. $359 \$ 21$ k.c., wynoszące do dnia 31 grudnia 2015 r. czterokrotność wysokości stopy kredytu lombardowego Narodowego Banku Polskiego, zaś od dnia 1 stycznia 2016 r., dwukrotność odsetek ustawowych stanowiących sumę stopy referencyjnej Narodowego Banku Polskiego i 3,5 punktów procentowych,

c) co do kosztów procesu w całości.

3. Oddala powództwo w pozostałym zakresie.

4. Zasądza od pozwanej P.G.I. spółki z ograniczoną odpowiedzialnością z siedzibą w G. na rzecz powódki K.G. kwotę 7.458 (siedem tysięcy czterysta pięćdziesiąt osiem) zł tytułem kosztów procesu.

5. Nakazuje pobrać na rzecz Skarbu Państwa - Sądu Okręgowego w Gorzowie Wlkp. kwoty:

- od powódki K.G. 28,80 (dwadzieścia osiem złotych osiemdziesiąt groszy) zł,

- od pozwanej P.G.I. spółki z ograniczoną odpowiedzialnością z siedzibą w Gorzowie Wlkp. 152,20 (sto pięćdziesiąt dwa złote dwadzieścia groszy) zł, tytułem nieuiszczonych kosztów sądowych. 
II. Oddala apelację w pozostałej części.

III. Zasądza od pozwanej P.G.I. spółki z ograniczoną odpowiedzialnością z siedzibą w G. na rzecz powódki K.G. kwotę 3.542 (trzy tysiące pięćset czterdzieści dwa) zł tytułem kosztów postępowania apelacyjnego.

\section{Uzasadnienie}

Powódka K.G. wniosła pozew przeciwko pozwanemu - P.G.I. sp. z o.o. w G., o pozbawienie $\mathrm{w}$ całości wykonalności tytułów wykonawczych obejmujących nakazy zapłaty wydane w postępowaniu upominawczym przez Sąd Rejonowy w Gorzowie Wlkp. z dnia 25.05.2006 r. w sprawie X Nc 4247/06 zaopatrzony w klauzulę wykonalności w dniu 22.08.2006 r. oraz z dnia 7.06.2006 r. w sprawie X Nc 4335/06 zaopatrzony w klauzulę wykonalności w dniu 17.11.2006 r. Swoje żądanie oparła na instytucji przedawnienia oraz podniosła, że zasądzone odsetki mają charakter lichwiarski, w związku z czym koniecznym jest ich zastąpienie odsetkami maksymalnymi. Nadto, wskazała, że wykonała ciążące na niej zobowiązanie, albowiem mąż powódki P.G. dokonał przelewu na konto J.R. w wysokości 1060 euro.

Pozwany P.G.I. sp. z o.o. w G., w odpowiedzi na pozew uznał powództwo co do nakazu zapłaty z dnia 25.05 .2006 r. sygn. akt X Nc 4247/06, w zakresie odsetek umownych za opóźnienie w wysokości 1\% dziennie, za okres od dnia 26.05.2006 r. do dnia 17.10.2011 r. oraz kosztów procesu, zaś co do nakazu zapłaty w postępowaniu upominawczym z dnia 7.06.2006 r. X Nc 4335/06, w zakresie odsetek umownych za opóźnienie w wysokości $1 \%$ dziennie, za okres od dnia 8.06 .2006 r. do dnia 17.10.2011 r., oraz kosztów procesu, wnosząc o oddalenie powództwa w pozostałej części.

Wyrokiem Sądu Okręgowego w Gorzowie Wielkopolskim z dnia 21 marca 2019 r., wydanym w sprawie o sygn. I C 749/18, pozbawiono wykonalności tytuł wykonawczy w postaci nakazu zapłaty w postępowaniu upominawczym Sądu Rejonowego w Gorzowie Wlkp. z dnia 7.06.2006 r., X Nc 4335/06 zaopatrzonego w klauzulę wykonalności, w części, tj. co do odsetek umownych w wysokości $1 \%$ dziennie od dnia 8.06.2006 r. do dnia 17.10 .2011 r. oraz co do kosztów procesu w kwocie 225,00 zł i co do części odsetek umownych naliczonych od kwoty $600,00 \mathrm{zł} \mathrm{w}$ wysokości $1 \%$ dziennie z okresu od 24.08.2004 r. do 7.06.2006 r. w kwocie 2.628,85 zł (pkt I); pozbawiono wykonalności tytuł wykonawczy w postaci nakazu zapłaty w postępowaniu upominawczym Sądu Rejonowego w Gorzowie Wlkp. z dnia 25.05.2006 r., X Nc 4247/06 zaopatrzonego w klauzulę wykonalności, w części, tj. co do odsetek umownych w wysokości $1 \%$ dziennie od dnia 26.05.2006 r. do dnia 17.10.2011 r. oraz co do kosztów procesu w kwocie 225,00 zł (pkt II); w pozostałej części powództwo oddalono (pkt III). Nadto, zasądzono 
od pozwanego na rzecz powódki kwotę 867,07 zł tytułem zwrotu kosztów procesu (pkt IV) oraz nakazano ściągnąć na rzecz Skarbu Państwa - Sądu Okręgowego w Gorzowie Wlkp. tytułem brakującej opłaty od pozwu: od powódki kwotę 106,20 zł, od pozwanego kwotę 73,80 zł.

Powyższe rozstrzygnięcie Sąd I instancji poprzedził ustaleniami faktycznych, z których w wynika, że 2.07.2004 r. powódka K.G. (wówczas N.) zawarła z J.R. umowę pożyczki kwoty 1.200,00 zł do dnia 2.08 .2004 r. z oprocentowaniem w wysokości 20\% (200,00 zł) płatnym z góry (przez potrącenie z kwoty wypłaconej pożyczki). Strony umowy zastrzegły odsetki umowne za zwłokę w spłacie pożyczki w wysokości 8,4\% dziennie. $\mathrm{W}$ dniu 20.03.2006 r. J.R. zawarł z pozwanym P.G.I. sp. z o.o. w G. umowę cesji wierzytelności wynikającej z ww. umowy pożyczki na rzecz pozwanego.

23.07.2004 r. powódka K.G. (wówczas N.) zawarła z J.R. umowę pożyczki kwoty $600,00 \mathrm{zł}$ do dnia 23.08.2004 r. z oprocentowaniem w wysokości 20\% (100,00 zł) płatnym z góry (przez potrącenie z kwoty wypłaconej pożyczki). Strony umowy zastrzegły odsetki umowne za zwłokę w spłacie pożyczki w wysokości 8,4\% dziennie. W dniu 21.03.2006 r. J.R. zawarł z pozwanym P.G.I. sp. z o.o. w G. umowę cesji wierzytelności wynikającej z ww. umowy pożyczki na rzecz pozwanego.

Sąd Rejonowy w Gorzowie Wlkp., X Wydział Cywilny wydał w dniu 7.06.2006 r. nakaz zapłaty w postępowaniu upominawczym w sprawie X Nc 4335/06, w którym zasądził od pozwanej K.N. (obecnie G.) na rzecz P.G.I. sp. z o.o. w G., kwotę $600,00 \mathrm{zł} \mathrm{z} \mathrm{umownymi} \mathrm{odsetkami} \mathrm{w} \mathrm{wysokości} \mathrm{1 \%} \mathrm{dziennie} \mathrm{od} \mathrm{dnia} \mathrm{24.08.2004} \mathrm{r.}$ do dnia zapłaty wraz z kwotą 225,00 zł tytułem kosztów procesu. Nakaz zapłaty zaopatrzono w klauzulę wykonalności 17.11.2006 r.

Sąd Rejonowy w Gorzowie Wlkp., X Wydział Cywilny wydał w dniu 25.05.2006 r. nakaz zapłaty w postępowaniu upominawczym w sprawie X Nc 4247/06, w którym zasądził od pozwanej K.N. (obecnie G.) na rzecz P.G.I. sp. z o.o. w G., kwotę $1.200,00 \mathrm{zł} \mathrm{z}$ umownymi odsetkami w wysokości 1\% dziennie od dnia 3.08.2004 r. do dnia zapłaty wraz z kwotą 225,00 zł tytułem kosztów procesu. Nakaz zapłaty zaopatrzono w klauzulę wykonalności 22.08.2006 r.

W świetle powyższych ustaleń faktycznych oraz $\mathrm{w}$ odwołaniu do przepisu art. $840 \$ 1$ pkt 2 k.p.c. Sąd Okręgowy uznał powództwo za częściowo zasadne.

W kwestii konieczności zastąpienia odsetek o charakterze lichwiarskim odsetkami maksymalnymi Sąd orzekający wskazał, że w sprawie nie znajdzie zastosowanie stanowisko Sądu Najwyższego wyrażone w uchwale z dnia 15.03.2018 r., III CZP 107/17, gdyż tytuł wykonawczy (oraz tytuł egzekucyjny) w tej sprawie postał po dniu 20.02.2016 r., a więc po zmianie przepisów, która mogłaby być uznana za zdarzenie o którym mowa w art. $840 \$ 1$ pkt 2 k.p.c. Sąd zaznaczył, że art. 840 $\$ 1$ pkt 2 k.p.c. dotyczy bowiem zdarzeń, które mały miejsce „po powstaniu tytułu 
egzekucyjnego", zaś w tej sprawie nowelizacja Kodeksu cywilnego wprowadzająca odsetki maksymalne weszła w życie w dniu 20.02.2006 r., a nakazy zapłaty wydano w dniach 25.05.2006 r. i 7.06.2006 r. Sąd Okręgowy przyjął, że skoro wejście w życie nowelizacji k.c. powódka uznaje za zdarzenie powodujące, że zobowiązanie stwierdzone tytułem wykonawczym w części lub w całości wygasło i nie może być egzekwowane, to wejście $\mathrm{w}$ życie nowelizacji przed powstaniem tytułu egzekucyjnego nie jest objęte zakresem normowania art. $840 \$ 1$ pkt 2 k.p.c. (jak wskazano wcześniej właściwym trybem postępowania w tej sprawie byłoby złożenie sprzeciwów od nakazów zapłaty).

Nadto Sąd podkreślił, że powództwo przeciwegzekucyjne nie służy podważaniu, czy doprowadzeniu do ponownego rozpoznania sprawy zakończonej prawomocnym orzeczeniem (w tym przypadku nakazem zapłaty, który ma moc wyroku). Sąd wyjaśnił, że jeśli powódka kwestionuje wysokość zobowiązania i uważa, że zasądzono w nakazie zapłaty odsetki zbyt wysokie $\mathrm{z}$ uwagi na przekroczenie zasady swobody umów - art. 3531 k.c. i ich sprzeczności z zasadami współżycia społecznego, to stan taki istniał już w chwili zawarcia umowy i wydania nakazu zapłaty. Zdaniem Sądu, w takiej sytuacji właściwą - i jedyną - ścieżką było złożenie sprzeciwu od nakazu zapłaty i podniesienie wskazanych zarzutów w sprzeciwie. W ocenie Sądu, nie jest zaś dopuszczalne w tym celu wykorzystywanie powództwa przeciwegzekucyjnego (art. $840 \$ 1$ pkt 2 k.p.c).

W związku z powyższym Sąd ustalił wysokość zadłużenia powódki na dzień dokonania zapłaty (4.10.2007 r.). Podkreślił, że odsetki od kwoty 1.200,00 zł należało naliczyć od 3.08.2004 r. do 4.10 .2007 r. (1158 dni), co daje kwotę 13.896,00 zł (12 x 1158); odsetki od kwoty 600,00 zł należało naliczyć od dnia 24.08 .2004 r. do 4.10.2007 r. (1137 dni), co daje kwotę 6.822,00 zł (6 x 1137). Jak wskazał Sąd, łącznie daje to kwotę 20.718,00 zł odsetek. Dalej Sąd wskazał, że całkowite zadłużenie wynosiło zaś w tym dniu (4.10.2007 r.) 1.800,00 zł należności głównej (1:200,00 zł +600,00 zł), 450,00 zł kosztów procesu (225,00 zł + 225,00 zł), 20.718,00 zł odsetek, tj. $22.968,00$ zł. Uwzględniając, że wpłata powódki wynosiła zaś kwotę $3.978,85$ zł (k. 52), uznano że nie doprowadziła do wygaśnięcia roszczenia pozwanego w całości. Doprowadziła do wygaśnięcia roszczenia co do kosztów procesu (450,00 zł) oraz wynagrodzenia pełnomocnika w egzekucji (900,00 zł) - sposób zaliczenia wpłaty na poczet należności - k. 37; pozostało zaś 2.628,85 zł (3.978,85 zł - 900,00 zł 450,00 zł) i tą kwotę należało zaliczyć na odsetki.

Ponadto, Sąd I instancji uznał za zasadne zarzuty odnoszące się do kwestii przedawnienia, obejmującej roszczenie z tytułu kosztów procesu $(450,00$ zł) i odsetek należnych $\mathrm{z}$ okresu od 24.08.2004 r. do 7.06.2006 r., ale tylko w części zaspokojonej z wpłaty z 4.10.2007 r., tj. w kwocie $2.628,85$ zł oraz co do odsetek za 
okres od 8.06.2006 r. do 17.10.2011 r. (X Nc 4335/06) oraz za okres od 6.05.2006 do 17.10.2011 r. (X Nc 4247/06).

Koszty procesu i nieuiszczone koszty sądowe rozliczono przy uwzględnieniu, że powódka wygrała proces w $41 \%$, zaś pozwany w $59 \%$.

Apelację od powyższego wyroku wniosła powódka, zaskarżając to orzeczenie w części, tj. co do pkt III, IV i V i zarzucając:

- sprzeczność istotnych ustaleń sądu I instancji z treścią zebranego w sprawie materiału dowodowego przez brak ustalenia, że w sprawie zachodzi zdarzenie powstałe po wydaniu tytułów wykonawczych, które powoduje niemożność ich egzekwowania w drodze egzekucji komorniczej, podczas gdy takim zdarzeniem powstałym po wydaniu tytułów wykonawczych - obok spłaty - jest brak możliwości zaspokojenia roszczenia na skutek żądania wygórowanych odsetek w wysokości 1\% dziennie, wskutek tego, że nakazy zapłaty w opisanym stanie faktycznym z uwagi na wartość należności głównej, obarczonej odsetkami we wskazanej w nakazach zapłaty wysokości, stanowią klasyczny przykład zakazanej lichwy; zdaniem skarżącej tak określone odsetki są sprzeczne ze społeczno-gospodarczym przeznaczeniem prawa i zasadami współżycia społecznego i z tej przyczyny nie mogą być egzekwowane,

- naruszenie przepisów prawa procesowego, a w szczególności art. $840 \$ 1$ pkt 2 k.p.c. przez jego niezastosowanie w sytuacji, gdy prawidłowa ocena treści nakazów zapłaty w opisanym stanie faktycznym powoduje, że nie mogą się one ostać $\mathrm{w}$ obrocie prawnym z tej przyczyny, że wartość należności głównej obarczonej odsetkami we wskazanej w nakazach zapłaty wysokości stanowi klasyczny przykład zakazanej lichwy i są sprzeczne ze społeczno-gospodarczym przeznaczeniem prawa i zasadami współżycia społecznego i z tej przyczyny nie mogą być egzekwowane,

- nierozpoznanie istoty sprawy, to jest braku dokonania przez Sąd oceny przesłanki wskazanej przez powódkę jako zdarzenia powstałego po wydaniu tytułów wykonawczych, powodującego niemożność prowadzenia egzekucji, w postaci braku możliwości zaspokojenia roszczenia na skutek żądania wygórowanych odsetek w wysokości 1\% dziennie, wskutek tego, że nakazy zapłaty w opisanym stanie faktycznym z uwagi na wartość należności głównej obarczonej odsetkami w wysokości wskazanej w nakazach zapłaty i stanowią klasyczny przykład zakazanej lichwy.

Uwzględniając powyższe, powódka wniosła o zmianę zaskarżonego wyroku poprzez pozbawienie w całości wykonalności tytułów wykonawczych obejmujących nakazy zapłaty wydane w postępowaniu upominawczym przez Sąd Rejonowy w Gorzowie Wielkopolskim z dnia 25 maja 2006 r. w sprawie X Nc 4247/06 opatrzony klauzulą wykonalności z dnia 22 sierpnia 2006 r. oraz z dnia 7 czerwca 
2006 r. w sprawie X Nc 4335/06 opatrzony klauzulą wykonalności z dnia 17 listopada 2006 r. Nadto, domagała się zasądzenia od pozwanego na swoją rzecz kosztów sądowych w tym kosztów zastępstwa procesowego za obie instancje.

Pozwany, odpowiadając na apelację, wniósł o jej oddalenie w całości oraz zasądzenie od powódki na swoją rzecz kosztów zastępstwa procesowego w postępowaniu apelacyjnym wg norm przepisanych.

\section{Sąd Apelacyjny zważył, co następuje:}

Apelacja powódki skutkowała wydaniem przez Sąd odwoławczy orzeczenia o charakterze reformatoryjnym, jednak $\mathrm{z}$ innych przyczyn niż te, które zostały w niej podniesione.

Tytułem uwag porządkujących Sąd Apelacyjny wskazuje, że zgodnie z treścią art. 9 ust, 4 ustawy z dnia 4 lipca 2019 r. o zmianie ustawy - Kodeks postępowania cywilnego oraz niektórych innych ustaw (Dz.U.2019.1469), która w zasadniczej części weszła w życie w dniu 7 listopada 2020 r., do rozpoznania środków odwoławczych wniesionych $i$ nierozpoznanych przed dniem wejścia $w$ życie niniejszej ustawy stosuje się przepisy ustawy zmienianej $w$ art. 1, w brzmieniu dotychczasowym. Skoro zatem, poddany pod osąd środek odwoławczy wniesiony został przed tą datą, do jego rozpoznania zastosowanie znajdują przepisy kodeksu postępowania cywilnego w brzmieniu nie uwzględniającym tej ustawy. Z kolei rozpoznanie sprawy na posiedzeniu niejawnym znajdowało oparcie w treści art. 15zzs ${ }^{3}$ ustawy z dnia 2 marca 2020 r. o szczególnych rozwiązaniach związanych z zapobieganiem, przeciwdziałaniem i zwalczaniem COVID-19, innych chorób zakaźnych oraz wywołanych nimi sytuacji kryzysowych (Dz. U. poz. 374, 567, 568, 695, 875), przy uwzględnieniu, że z jednej strony w wynikającym z tego przepisu terminie żadna ze stron nie złożyła wniosku o rozpoznanie sprawy na rozprawie po doręczeniu im postanowienia Sądu Apelacyjnego z dnia 3 czerwca 2020 r. o skierowaniu sprawy do rozpoznania na posiedzeniu niejawnym, z drugiej zaś, że w uwarunkowaniach niniejszej sprawy nie zachodziły jakiekolwiek okoliczności które, uzasadniałyby potrzebę wyznaczenia takiej rozprawy pomimo braku takiego wniosku.

Zgodnie z art. 382 k.p.c. Sąd II instancji orzeka na podstawie materiału procesowego zebranego w postępowaniu w pierwszej instancji oraz w postępowaniu apelacyjnym. Z regulacji tej wynika, że postępowanie apelacyjne polega na merytorycznym rozpoznaniu sprawy. Obowiązek rozpoznania sprawy w granicach apelacji (art. 378 \$ 1 k.p.c.), oznacza wyłącznie związanie sądu odwoławczego zarzutami prawa procesowego (tak Sąd Najwyższy m.in. w uchwale z dnia 31 stycznia 2008 r., sygn. akt III CZP 49/07), za wyjątkiem tego rodzaju naruszeń, które skutkują nieważnością postępowania. Ograniczenie to nie dotyczy zaś kwestii 
materialnoprawnych, a powinnością Sądu II instancji jest pełna ocena zgłoszonego pozwem roszczenia $\mathrm{z}$ punktu widzenia norm prawa materialnego, niezależnie od zgłoszonych w tym zakresie w apelacji zarzutów.

Wykonując ten obowiązek, Sąd Apelacyjny dokonał własnej oceny przedstawionego pod osąd materiału procesowego i w jej wyniku stwierdził, że Sąd Okręgowy w sposób prawidłowy przeprowadził postępowanie dowodowe, a poczynione ustalenia faktyczne (zawarte w wyodrębnionej redakcyjnie części uzasadnienia zaskarżonego wyroku) nie są wadliwe i znajdują odzwierciedlenie w treści przedstawionych w sprawie dowodów. Sąd odwoławczy ustalenia Sądu Okręgowego czyni częścią uzasadnienia własnego wyroku, nie znajdując potrzeby ponownego ich szczegółowego przytaczania.

W pierwszej kolejności odnieść się należało do zarzutu nierozpoznania istoty sprawy, skonstruowanego na twierdzeniu, jakoby Sąd Okręgowy nie odniósł się do kwestii braku możliwości zaspokojenia roszczenia na skutek żądania wygórowanych odsetek w wysokości 1\% dziennie, stanowiących przykład zakazanej lichwy. Wyjaśnienia w tym kontekście wymaga, że nierozpoznanie istoty sprawy - w rozumieniu art. $386 \$ 4$ k.p.c. - oznacza zaniechanie przez sąd pierwszej instancji zbadania materialnej (istotnej) podstawy żądania pozwu albo całkowite pominięcie merytorycznych zarzutów pozwanego (tak m.in. Sąd Najwyższy w wyroku z dnia 21 października 2005 r., III CK 161/05, Lex nr 178635). Innymi słowy, nierozpoznanie istoty sprawy można ująć jako niewyjaśnienie i pozostawienie poza oceną okoliczności faktycznych, stanowiących przesłanki zastosowania normy prawa materialnego, będącej podstawą roszczenia (por. orzeczenie Sądu Najwyższego z dnia 11 marca 1998 r., II CKN 411/97). W ocenie Sądu Apelacyjnego, o tego rodzaju nierozpoznaniu istoty sprawy $\mathrm{w}$ przedmiotowej sprawie nie może być mowy. Podkreślić należy, że Sąd Okręgowy szczegółowo odniósł się do wszystkich twierdzeń strony powodowej, w tym także tych związanych z lichwiarskich charakterem zasądzonych odsetek i relacji tych odsetek do instytucji odsetek maksymalnych, wprowadzonych do polskiego porządku prawnego w dniu 20 lutego $2006 \mathrm{r}$. ustawą z dnia 7 lipca 2005 r. o zmianie ustawy - Kodeks cywilny oraz o zmianie niektórych innych ustaw (Dz. U. Nr 157, poz. 1316). Zauważenia wymaga, iż Sąd I instancji wprost wskazał, że wobec wejścia rzeczonej nowelizacji przed wydaniem kwestionowanych obecnie tytułów wykonawczych nie jest możliwe przyjęcie, że owa nowelizacja jest zdarzeniem prawnym, o którym mowa w art. $840 \$ 1$ pkt 2 k.p.c. Natomiast sama okoliczność, iż Sąd I instancji nie rozstrzygnął kwestii wpływu wprowadzenia odsetek maksymalnych (ograniczających lichwiarską wysokość uprzednio zasądzanych odsetek) w sposób żądany przez powódkę, nie uprawnia do wnioskowania, że doszło do nierozpoznania istoty sprawy. 
W dalszej kolejności, celem uporządkowania sytuacji procesowej, wskazania wymaga, że analiza uzasadnienia apelacji prowadzi do wniosku, że została ona w praktyce oparta na zarzutach naruszenia prawa materialnego, bowiem powódka w rzeczywistości kwestionuje nie tyle ustalenia faktyczne dokonane w sprawie, co ocenę i wnioski prawne wyciągnięte z poczynionych ustaleń, co skutkowało oddaleniem żądania powódki. Oczywiście nie można pominąć, że wprawdzie w apelacji sformułowano zarzut sprzeczności istotnych ustaleń faktycznych, jednak w istocie rzeczy dotyczy uchybienia przez Sąd Okręgowy określonym przepisom prawa materialnego. Zwrócić bowiem należy uwagę, iż w ramach tego zarzutu powódka zarzuca wyłącznie, że Sąd I instancji błędnie przyjął jakoby zasądzenie odsetek o charakterze lichwiarskim nie było zdarzeniem uniemożliwiającym egzekucję należności. Dekodując zatem stanowisko skarżącej w tym zakresie, zauważyć trzeba, że nie kwestionuje ona w żaden sposób dokonanych przez Sąd Okręgowy ustaleń faktycznych w tych aspektach, choćby poprzez wskazanie błędów w ocenie materiału procesowego, stanowiącego kanwę tych ustaleń, a wyłącznie poprzestaje na kwestionowaniu uprawnienia tego Sądu do wyprowadzenia - w uwarunkowaniach przedmiotowej sprawy - wniosków opisanych w zarzutach apelacji. Tego rodzaju sposób argumentacji, kwalifikowany być winien, na płaszczyźnie procesowej, jako zarzut obrazy prawa materialnego, dotyczący - ściślej rzecz ujmując - fazy jego subsumcji do ustalonego stanu faktycznego. Rozważenie bowiem czy doszło do zdarzenia uniemożliwiającego egzekucję, czy też powodującego wygaśnięcie zobowiązania nie dotyczy wadliwych ustaleń faktycznych, będących konsekwencją oceny dowodów, dokonanej z przekroczeniem art. $233 \$ 1$ k.p.c., lecz obejmują zagadnienia sui generis materialnoprawne, związane z kwalifikacją okoliczności faktycznych z punktu widzenia dyspozycji art. $840 \$ 1$ pkt 2 k.p.c.

Dokonując materialnoprawnej oceny prawnej powództwa, stwierdzić należy, że prawidłowe (i jako takie niewymagające uzupełnienia i korygowania) są wywody Sądu Okręgowego, upatrującego podstawy prawnej powództwa w treści art. 840 $\$ 1$ pkt 2 k.p.c. Zauważenia przy tym wymaga, iż kwestią poddaną ocenie Sądu Apelacyjnego jest wyłącznie rozważenie, czy zdarzeniem powodującym wygaśnięcie zobowiązania albo powodującym niemożność egzekucji - w rozumieniu powyższej regulacji - jest zmiana stanu prawnego w zakresie odsetek należnych, obowiązująca od dnia 20 lutego 2006 r., na mocy opisanej wyżej ustawy. Wyjaśnić jednocześnie należy apelującej, że to nie sam lichwiarski charakter zasądzonych odsetek winien być kwalifikowany jako takie zdarzenie - tak jak mogłyby wskazywać na to twierdzenia apelacji - a jedynie wspomniana nowelizacja, obejmująca wprowadzenie instytucji odsetek maksymalnych. Trudno bowiem uznać jakoby brak możliwości zaspokojenia roszczenia z uwagi na wysokość świadczenia mógłby samoistnie determinować rozstrzygnięcie w niniejszej sprawie. Oczywistym jest, iż 
przyjęcie stanowiska powódki prowadziłoby do irracjonalnych sytuacji, w których podstawą pozbawienia wykonalności tytułu wykonawczego mogłaby być już tylko niemożność świadczenia, która w postępowaniu egzekucyjnym nie jest okolicznością o charakterze wyjątkowym.

I tak, przechodząc do oceny istoty sporu, wskazania wymaga, że rację ma Sąd Okręgowy, przyjmując, iż powództwo opozycyjne, skierowane przeciw tytułowi wykonawczemu, którym jest prawomocne orzeczenie sądowe, nie może służyć ponownemu merytorycznemu rozpoznaniu sprawy. Nie jest ono bowiem środkiem prawnym, za pomocą którego można by podważyć prawomocność materialną orzeczenia (por. uchwałę Sądu Najwyższego z dnia 23 maja 2012 r., III CZP 16/12, OSNC 2012, Nr 11, poz. 129). Z tego też względu zasadniczo jurydycznie trafna jest teza, iż w związku z tym, że kwestionowane tytuły wykonawcze powstały po dniu 20 lutego 2016 r., a zatem już po zmianie normatywnej wynikającej z ustawy z 2005 r., nie jest możliwym dokonywanie oceny prawidłowości nakazów zapłaty z dnia 25 maja 2006 r. i 7 czerwca 2006 r. na płaszczyźnie zgodności z treścią przepisu art. $359 \$ 21$ k.p.c. oraz art. $359 \$ 22$ k.p.c., albowiem przepis art. $840 \$ 1$ pkt 2 k.p.c. wymaga, aby zdarzenie powodujące wygaśnięcie zobowiązania albo niemożność jego egzekwowania miało miejsce po powstaniu tytułu wykonawczego. Rzecz jednak w tym, że oceniając zasadność powództwa za okres po powstaniu tytułów egzekucyjnych, Sąd Okręgowy nie uwzględnił szczególnego charakteru należności odsetkowych, związanego z wymagalnością tych świadczeń.

Wskazać w tym miejscu należy, że odsetki za opóźnienie mają charakter świadczenia okresowego, które jak podnosi się w judykaturze (por. uchwała składu siedmiu sędziów Sądu Najwyższego z dnia 16 stycznia 2005 r., III CZP 42/04, OSNC 2005, nr 9, poz. 149), charakteryzuje zależność rozmiaru należności od upływu czasu oraz układanie się świadczeń w szereg kolejno po sobie wymagalnych świadczeń, przy czym mają one występować w równych odstępach czasu. Okresowy charakter odsetek za opóźnienie przejawia się w tym, że z każdym dniem opóźnienia powstaje wobec dłużnika odrębne roszczenie o odsetki, które jest także od tego dnia wymagalne i od tego dnia zaczyna się przedawniać (m.in. uchwała składu siedmiu sędziów z dnia 26 stycznia 2005 r., III CZP 42/04, oraz uchwały Sądu Najwyższego z dnia 5 kwietnia 1991 r., III CZP 21/91, OSNC 1991, nr 10-12, poz. 121, z dnia 9 listopada 1994 r., III CZP 141/94, „Monitor Prawniczy” 1995, nr 3, s. 83).

Uznając zaś każdy kolejny dzień niewykonania zobowiązania pieniężnego za odrębne zdarzenia oznaczające poszczególne wypadki niewykonania zobowiązania, wywieść należy, że prawem właściwym dla odsetek za opóźnienie powinno być prawo obowiązujące w dniu, za który należą się odsetki (tak też Sąd Najwyższy w uzasadnieniu uchwały z dnia 15 marca 2018 r., III CZP 107/17, Lex nr 2467066; wyrok Sądu Najwyższego z dnia 28 sierpnia 2019 r., IV CSK 438/18, Lex nr 2727404). 
Przekładając powyższe uwagi teoretyczne do realiów przedmiotowej sprawy, stwierdzić należy, że jakimkolwiek zdarzeniem prawnym, o którym mowa w art. $840 \$ 1$ pkt 2 k.p.c., mogącym stanowić podstawę pozbawienia wykonalności tytułu wykonawczego, jest obowiązywanie od dnia 20 lutego 2006 r. ustawy z dnia 7 lipca 2005 r., wprowadzającej instytucję odsetek maksymalnych (art. $359 \$ 21$ i 22 k.c.), to jednak jego kwalifikacja na tej płaszczyźnie uwzględniać musi opisaną wyżej naturę roszczenia odsetkowego. Skoro zaś odsetki aktualizują się (stają się wymagalne) w każdym kolejnym dniu, toteż ocena taka polegać musi na weryfikacji, czy w datach ich wymagalności (w praktyce w każdym kolejnym dniu), wartość odsetek umownych naruszała bezwzględnie obowiązująca normę art. $359 \$ 21$ k.c. Oczywistym jest przy tym, że stosownie do przedstawionych wyżej uwarunkowań prawnych, weryfikacja taka nie może dotyczyć odsetek umownych, które były wymagalne przed datami wydania przez Sąd Rejonowy w Gorzowie Wielkopolskim nakazów zapłaty w postępowaniu upominawczym, odpowiednio, 25 maja 2006 r. w sprawie X Nc 4247/06 oraz 22 sierpnia 2006 r. w sprawie X Nc 4335/06. Prowadziłoby to bowiem wprost do weryfikacji treści tych orzeczeń poprzez odwołanie się do zdarzeń w całości istniejących w datach ich wydania, co jest oczywiście niedopuszczalne. Całkowicie odmienna sytuacja zachodzi natomiast $\mathrm{w}$ zakresie wynikających z nakazów zapłaty odsetek umownych za okres po ich wydaniu. Jak już wskazano, świadczenia te stały się w sposób periodyczny wymagalne już po powstaniu tych tytułów egzekucyjnych, a to dopiero aktualizowało możliwość odniesienia do nich zmian wprowadzonych nowelą z dnia 7 lipca $2005 \mathrm{r}$.

Treść art. $359 \$ 21$ k.c. nie pozostawia jakichkolwiek wątpliwości co do tego, że odsetki wynikające z czynności prawnej nie mogą przekroczyć zdefiniowanych $\mathrm{w}$ tym przepisie odsetek maksymalnych. Od dnia wejścia w życie tego przepisu, tj. 20 lutego 2005 r., wygasły zobowiązania do zapłaty odsetek za opóźnienie w zakresie przewyższającym odsetki maksymalne (tak. Min. Sądu Najwyższy w powołanym wyżej wyroku z dnia 28 sierpnia 2019 r. IV CSK 438/18. Oznacza to w konsekwencji, że za okres liczony od dnia następnego po datach wydania przedmiotowych nakazów zapłaty, zaktualizował się - na podstawie dyspozycji art. $840 \$ 1$ pkt 2 k.p.c. - obowiązek pozbawienia wykonalności kwestionowanych przez powódkę tytułów wykonawczych w tej części, w jakiej określone w nich odsetki umowne przekraczały odsetki maksymalne. Zważywszy zaś na treść punktów I i II zaskarżonego wyroku, w których Sąd Okręgowy częściowo pobawił tego tytułu wykonawcze wykonalności, uwzględniając dokonaną przez męża powódki wpłatę oraz zarzut przedawnienia, praktyczna ingerencja sądu odwoławczego w ich treść polegała na redukcji odsetek - po uwzględnionym przez Sąd Okręgowy okresie przedawnienia - do wysokości odsetek maksymalnych, zgodnych z treścią art. $359 \$ 21$ 
k.c., uwzględniających zmiany w treści tego przepisu, które weszły w życie z dniem 1 stycznia 2016 r. (vide: pkt I.2.c oraz I.2.b sentencji).

Sąd Apelacyjny zauważa w tym miejscu, że opisane wyżej stanowisko w całości odpowiada tezom końcowej części uzasadnienia odpowiedzi na apelację, w której pozwany wprost wskazał, że nie jest on uprawniony do domagania się od powódki odsetek wyższych niż odsetki maksymalne (k. 203-204). Tego rodzaju teza pozostawała zatem w oczywistej sprzeczności do jego wniosku, w którym postulował oddalenie apelacji powódki w całości.

Konsekwencję zmiany rozstrzygnięcia co do istoty sprawy, stanowił obowiązek jego modyfikacji także w zakresie kosztów procesu, a to z uwagi na zmianę proporcji, w jakich każda ze stron utrzymała się ze swoimi wnioskami. Punkt wyjścia do ustalenia tych proporcji stanowi wskazanie, że wedle przyjętego przez Sąd Okręgowy rozliczenia powódka wygrała proces w zakresie kwoty $38.478,85 \mathrm{zl}$, tj. w około $41 \%$. Dodatkowo wygrała ona to postępowanie co do odsetek do obu tytułów, w zakresie różnicy między odsetkami umownymi a maksymalnymi. Kwota odsetek maksymalnych obliczonych od obu należności głównych za okres od 18 października 2011 r. do dnia 10 lipca 2018 r., tj. dnia wniesienia pozwu wyniosła 4.034,37 zł Z kolei odsetki umowne od tych należności wynoszą sumarycznie $6.570 \mathrm{zł} \mathrm{rocznie,}$ a za cały ten okres $44.190 \mathrm{zł}$ (6 lat x $6.570 \mathrm{zł}+4,770 \mathrm{zł}$ odsetek za okres od 18 października 2017 do 10 lipca 2018 r.). Różnica między tak ustalonymi wartościami odsetek umownych i maksymalnych to kwota, po zaokrągleniu, 40.155 zł. Oznacza to, że powódka wygrała proces co od kwoty $78,633,85 \mathrm{zl}$, co w stosunku do wartości przedmiotu sporu wynoszącej $93.447,46 \mathrm{zł}$, stanowi około $84 \%$. W pozostałej części, tj. w około $16 \%$, to pozwany utrzymał się ze swoimi wnioskami. Jak prawidłowo przyjął Sąd Okręgowy, koszty powódki wyniosły 9.910 zł, z czego 84\% to kwota 8324,40 zł. Z kolei koszty pozwanego to kwota 5.417 zł, z czego $16 \%$ to kwota 866,72 zł. Kompensata tych wartości i zaokrąglenie powstałej w jego wyniku sumy, skutkowało zasądzeniem $\mathrm{z}$ tego tytułu od pozwanego na rzecz powódki kwoty $7.458 \mathrm{zt}$, na podstawie art. 100 zd. 1 k.p.c.

$\mathrm{W}$ zmienionych proporcjach, tj. powódkę w $16 \%$, zaś pozwanego w $84 \%$, należało obciążyć strony - w oparciu o art. 113 ust. 1 ustawy o kosztach sądowych w sprawach cywilnych - nieuiszczonymi kosztami sądowymi w postaci brakującej opłaty od pozwu w kwocie $180 \mathrm{zt}$.

$Z$ tych wszystkich względów, na podstawie art. $386 \$ 1$ k.p.c. konieczne było wydanie wyroku reformatoryjnego, o treści jak w punkcie I sentencji. Dalej idąca apelacja powódki podlegała oddaleniu jako bezzasadna, stosownie do dyspozycji art. 385 k.p.c.

O kosztach postępowania apelacyjnego orzeczono na podstawie art. $108 ₫ 1$ k.p.c. w zw. z art. 100 zd. 1 k.p.c., zgodnie z zasadą ich stosunkowego rozdzielenia. 
Przy wartości przedmiotu zaskarżenia wynoszącej 58.048 zł, powódka utrzymała się ze swoimi żądaniami, wedle przedstawionego wyżej wyliczenia co do kwoty $40.155 \mathrm{zł}$ a zatem wygrała ona postępowanie odwoławcze w około $69 \%$. W pozostałej części, tj. w około $31 \%$, postępowanie to wygrał pozwany.

Koszty powódki wyniosły kwotę 6.953 zł, na którą złożyły się:

- $2.903 \mathrm{zl}$ - opłata od apelacji,

- $4.050 \mathrm{zł}$ - wynagrodzenie pełnomocnika, w stawce minimalnej, wynikającej $\mathrm{z} \$ 2$ pkt $6 \mathrm{w}$ zw. z $\$ 10$ ust. 1 pkt 2 rozporządzenia Ministra Sprawiedliwości z dnia 22 października 2015 r. w sprawie opłat za czynności adwokackie, z czego $69 \%$ to kwota $4.797,57 \mathrm{zł}$.

Z kolei koszty pozwanego zamknęły się kwotą 4.050 zł, stanowiącą wynagrodzenie jego pełnomocnika $\mathrm{w}$ stawce minimalnej, ustalone na podstawie $\$ 2$ pkt 6 w zw. z $\$ 10$ ust.1 pkt 2 rozporządzenia Ministra Sprawiedliwości z dnia 22 października 2015 r. w sprawie opłat za czynności radców prawnych. z czego 31\% to kwota $1.255,50 \mathrm{zł}$.

Kompensata tak ustalonych należności skutkowała rozstrzygnięciem jak w punkcie III sentencji. 